\title{
Physicochemical properties of Salvia miltiorrhiza Bunge following treatment with enzymes
}

\author{
Sun-Hwa Kim ${ }^{1}$, In-Wook Hwang ${ }^{2}$, Shin-Kyo Chung ${ }^{2,3}$, Young-Jin Seo ${ }^{4}$, Jong-Soo Kim ${ }^{4}$, \\ Yong-Jin Jeong ${ }^{1,5}$, Mi-Yeon $\mathrm{Kim}^{1 *}$ \\ ${ }^{1}$ KMF Co., Ltd., Daegu 41065, Korea \\ ${ }^{2}$ Food and Bio-Industry Research Institute, Kyungpook National University, Daegu 41566, Korea \\ ${ }^{3}$ School of Food Science and Biotechology, Kyungpook National University, Daegu 41566, Korea \\ ${ }^{4}$ Bonghwa Plant Experiment Station, Bonghwa 36229, Korea \\ ${ }^{5}$ Department of Food Science and Technology, Keimyung University, Daegu 42403, Korea
}

\section{효소 처리에 따른 단삼 추출물의 이화학적 특성}

\author{
김선화 $^{1} \cdot$ 황인욱 $^{2} \cdot$ 정신교 $^{2,3} \cdot$ 서영진 $^{4} \cdot$ 김종수 $^{4} \cdot$ 정용진 $^{1,5} \cdot$ 김미연 ${ }^{1 *}$ \\ ${ }^{1}$ (주)케이엠에프, ${ }^{2}$ 경북대학교 식품생물산업연구소, ${ }^{2}$ 경북대학교 식품공학과, ${ }^{3}$ 봉화약초시험장, \\ ${ }^{4}$ 계명대학교 식품가공학과
}

\begin{abstract}
To improve the utilization of the domestic plant Salvia miltiorrhiza Bunge (Danshen), this study investigated changes in the physicochemical qualities of Danshen extracts obtained from low-temperature extraction using the enzymes amylase, cellulase, pectinase, and protease. Changes in the yield, $\mathrm{pH}$, sugar content, and chromaticity were investigated. The changes were found to be highest in the amylase-treated extract with the following values: yield, $58.3 \%$; $\mathbf{p H}$, 6.04; sugar content, $5.97^{\circ}$ Brix. With regard to antioxidant properties, Danshen extracts treated with amylase showed the highest DPPH and ABTS scavenging activities of $84.25 \%$ and $74.11 \%$ at $55 \mathrm{ppm}$. The total phenolic compound content was highest in the group subjected to enzyme treatment at $60{ }^{\circ} \mathrm{C}$. The salvianolic acid B level of the Danshen extract was the highest in the amylase-treated group, with a value of 3,002.6 mg/100 g. Cryptotanshinone level was the highest in the amylase- and protease-treated group with a value of $3.8 \mathrm{mg} / 100 \mathrm{~g}$. Tanshinone I was the highest in the protease-treated group, with a value of $14.2 \mathrm{mg} / 100 \mathrm{~g}$. The results showed that the indicator components of Danshen were detected as stable in the extracts after using amylase for low-temperature extraction; therefore, it would be possible to use Danshen industrially as a functional ingredient through mass production. Furthermore, the enzyme-treatment extraction could be utilized for a variety of natural products.
\end{abstract}

Key words : Salvia miltiorrhiza, enzyme treated extract, radical scavenging activity, total phenol content, salvionolic acid B

\section{서 론}

최근 경제 성장과 더불어 소득수준의 향상에 따라 건강 에 대한 관심이 높아짐에 따라 식품으로부터 유래되는 생리

*Corresponding author. E-mail : kite0717@gmail.com Phone : 82-53-584-6523, Fax : 82-53-584-6524

Received 21 September 2015; Revised 8 October 2015; Accepted 12 October 2015.

Copyright (c) The Korean Society of Food Preservation. All rights reserved.
활성을 지닌 한약재 및 한약재를 이용한 건강 기능성 식품 들이 소비자들로부터 큰 반향을 얻고 있다(1). 천연물을 활용한 기능성 식품 및 의약품개발에 대한 연구는 아시아뿐 아니라 세계적으로 증가하는 추세로, 많은 연구자들에 의 해 천연물에 함유되어 있는 유효성분과 효능에 대한 과학적 검증이 이루어지고 있다. 현 대에는 한약재를 이용한 고부 가가치 식 - 의약품을 개발하여 막대한 이익 창출이 가능한 시대로 변화하면서(2), 한약재가 단순히 약재로서의 기능 뿐 만 아니라 건강기능성 식품으로의 전환에 따른 시장 선점을 위해서는 제품 및 지적재산권의 확보가 필수적이 
되었다(1). 한국 식품의약품안전청 등에 고시된 많은 식물 중 식용 가능한 한약재는 176종 정도이며, 그 중 한약재를 이용한 일반식품으로의 가공방법에는 식품 제조시 식품 공전상 식품 원료로 사용이 허가된 생약재를 이용하여 건강 음료 $(3,4)$, 전통주 $(5,6)$, 건조분말을 이용한 떡(7) 및 제빵 $(8)$ 제조 등이 있다. 한약재로의 추출조건에 대한 연구는 용매 추출하여 항산화성 효과를 본 삼백초(9), 전처리조건에 따 른 맥문동의 특성(10), 상온추출을 이용한 산사자의 트롬빈 면역(11), 초음파를 이용하여 저온추출한 마황과 복분자의 면역 활성(12), 효소 처리에 의한 참당귀 다당체 분리(13), 황기 효소분해물 열수 추출액의 이화학적 특성(14) 등과 같이 다양한 한약재 기원 천연물 활용을 위한 연구가 진행 되고 있으나, 한약재 성분의 추출수율을 고려한 추출법에 따른 이화학적 특성 분석 및 가공방법의 개발에 관한 연구 는 미비한 실정이다.

단삼(Salviae Miltiorrhizae Radix)은 꿀풀과(Labiatae)에 속한 다년생 초본으로 중국이 원산지이며 뿌리와 뿌리줄기 를 건조한 것으로 봄과 가을에 채취하여 진흙을 제거하고 쇄건(碱乾)한 것을 약용으로 사용하고 있다(15). 2012년 처 음 국내 생산이 성공함에 따라 중국산과 국내산의 비교에 대한 연구 및 가공법 개발을 위한 추출조건의 최적화 및 특성에 대한 연구가 시급한 실정이다. 건조한 단삼은 거칠 고 세로 주름이 있으며 표피에 적색 색소가 침착되어 한약 재료로 사용되고, 활혈거어(活血祛瘀, 조경지통(調經止通), 양혈안신(養血安神), 양혈소옹(凉血消㾦) 등에 효능이 있는 것으로 알려져 있다(16). 한의학에서는 어혈성의 심복부동 통, 타박상 치료와 불면증, 피부발진 등에 이용하는 약재이 며(17), 식품 공전 내용 중 뿌리부분을 제한적 식품원료로 수록되어 있어, 식품 제조 가공에서 부원료로 사용할 수 있다(18). 단삼의 주요성분으로는 Tanshinone I, ПА, ПB 등을 포함하는 diterpene화합물과, Danshensu(salvianic acid A), Protocatechuic aldehyde, Salvianolic acid B 등을 포함하 는 phenolic 화합물 등이 알려져 있다(19). 현재까지 단삼에 관한 연구로는 용매와 추출조건에 따른 단삼추출물의 항균 력(20), 단삼 분획 추출물의 암예방 효과(21), 단삼성분의 정량법 및 항염증 활성에 대한 연구(22), 단삼 메탄올추출물 의 항염증 효과(23), 단삼의 활성성분인 크립토탄시논의 심장보호효과(24), 단삼추출물의 암세포에 미치는 영향 (25), 달임조건에 따른 salvianolic acid B의 구조변환 차이 (26), 단삼추출물의 항산화 효과에 의한 RAW264.7 cell에서 의 항염증 작용(27) 등이 보고되어 있으며, 대부분 중국 수입산 원료가 이용되고 있다.

본 연구는 중국 수입에 의존하였던 단삼의 국내 재배에 성공으로 유효성분 극대화를 위하여 이화학적 특성을 조사 하였으며, 저온 추출에 따른 추출물의 이화학적 특성을 비 교 조사하여 산업적으로 활용 가능한 최적 추출조건을 설정 하고자 하였다.

\section{재료 및 방법}

\section{재료 및 시약}

본 실험에 이용된 단삼은 2014년 경북 봉화군에서 재배· 건조한 1년생을 영양단삼으로부터 구입하여 재료로 사용 하였다. 이때 사용된 건조된 단삼원료의 수분, 탄수화물, 조단백, 조지방, 회분 및 환원당은 각각 $6.83,64.17,16.0$, $0.0,4.1$ 및 $8.9 \%$ 이다. 본 실험에 이용된 1,1-diphenyl-2picrylhydrazyl(DPPH), salvianolic acid B, cryptotanshinone, tanshinone I 및 tanshinone $\Pi \mathrm{A}$, acetonitrile은 $\mathrm{Sigma}(\mathrm{St}$. Louis, Mo, USA)로부터 구입하여 사용하였다.

\section{시료 추출물 제조}

단삼의 추출조건은 다음과 같다. 국내산 단삼 $200 \mathrm{~g}$ 을 칭량하고 3 차 증류수 $2 \mathrm{~L}$ 와 혼합하여 $100^{\circ} \mathrm{C}$ 에서 30 분간 추출한 후 방냉하여 각각의 효소제를 첨가하여 진탕 항온기 (HB-205SW, Hanback Sci., Co., Incheon, Korea)를 이용하여 45 및 $60^{\circ} \mathrm{C}$ 에서 4 시간 추출하여 여과지(Whatman No. 41)로 여과한 추출액을 이용하였다.

\section{추출수율, $\mathrm{pH}$ 및 당도 측정}

각 조건에서 얻어진 단삼 추출물의 추출수율은 추출액 $10 \mathrm{~mL}$ 을 취하여 $105^{\circ} \mathrm{C}$ 에서 증발 건조(HB-502M, Hanbaek Scientific Co., Incheon, Korea)시켜 그 무게를 측정하여 사 용된 원료 양의 백분율로 추출수율을 나타내었다(28). 단삼 추출액의 $\mathrm{pH}$ 는 $\mathrm{pH}$ meter(Metrohm 691, Metrohm UK Ltd., Herisau, Switzerland)를 이용하여 측정하였다. 당도는 digital refractometer(PR-101, Atago Co., Tokyo, Japan)를 사 용하여 측정하였다.

\section{색도 및 갈색도 측정}

시료추출물의 색도는 UV-visible spectrophotometer(UV1601, Shimadzu Co., Kyoto, Japan)를 이용하여 L(lightness), $a$ (redness), $b$ (yellowness)를 각각 측정하여 Hunter's color value로 나타내었다. UV-visible spectrophotometer의 대조 구는 증류수 $(\mathrm{L}=100.00, \mathrm{a}=0.06, \mathrm{~b}=-0.09)$ 를 사용하였다. 단 삼 시료 추출물의 갈색도는 $420 \mathrm{~nm}$ 에서 측정하였다.

\section{총 페놀성 화합물 함량}

총 페놀성 화합물 함량은 Folins-Denis법(29)을 이용하여 비색 정량하였다. 시료 추출물 $2 \mathrm{~mL}$ 에 $50 \%$ phenol reagent (Folin-Ciocalteu's reagent) $2 \mathrm{~mL}$ 을 첨가하여 3 분간 방치 후 $10 \% \mathrm{Na}_{2} \mathrm{CO}_{3}$ 용액을 $2 \mathrm{~mL}$ 을 가한 다음 실온에서 30 분간 정치 발색시키고 UV-visible spectrophotometer(UV-1601, Shimadzu Co.)를 이용하여 $700 \mathrm{~nm}$ 에서 흡광도를 측정하였 다. 이때 gallic acid(Yakuri pure chemicals Co., Ltd., Kyoto, Japan)를 농도별로 조제한 후 상기의 방법으로 작성한 표준곡 선으로부터 환산하였으며 대조구는 증류수를 사용하였다. 


\section{DPPH radical 소거능}

DPPH(1,1-diphenyl-2-picrylhydrazyl, sigma) 라디칼 소거 활성은 Blois방법(29)을 변형하여 측정하였다. DPPH 0.15 $\mathrm{mM}$ 을 absolute ethanol $100 \mathrm{~mL}$ 에 용해한 후, $50 \%$ ethanol용 액을 대조구로 하여 $517 \mathrm{~nm}$ 에서 $\mathrm{DPPH}$ 용액의 흡광도를 약 1.0 이 되도록 희석하여 사용하였다. 시료 $0.5 \mathrm{~mL}$ 에 $\mathrm{DPPH}$ 용액 $5 \mathrm{~mL}$ 을 혼합하여 정확히 3 분 동안 반응시킨 후 UV-visible spectrophotometer(UV-1601, Shimadzu Co.) 를 이용하여 $517 \mathrm{~nm}$ 에서 흡광도를 측정하여 아래의 식으로 부터 DPPH radical 소거활성을 계산하였다.

$$
\text { DPPHradical scavengingactivity }(\%)=\left(1-\frac{A s}{A c}\right) \times 100
$$

As : Absorbance of group with sample

Ac : Absorbance of group without sample

Table 1. Optimum hydrolysis conditions of the enzymes used for preparation of the enzymatic extracts

\begin{tabular}{llcc}
\hline \multirow{2}{*}{ Enzymes } & \multicolumn{2}{c}{ Product Co. } & \multicolumn{2}{c}{ Optimum hydrolysis conditions } \\
& & $\mathrm{pH}$ & Temp. $\left({ }^{\circ} \mathrm{C}\right)$ \\
\hline Glucoamylase & DaiwaKASEI & $4.0 \sim 6.0$ & $50 \sim 60$ \\
Cellulase & AB Enzymes & 6.0 & 45 \\
Rapidase C80 Max & DSM Food Specialities & 4.5 & 40 \\
ProteAX & Amano enzyme Inc & $6.0 \sim 9.0$ & $40 \sim 60$ \\
\hline
\end{tabular}

\section{ABTs radical 소거 활성 측정}

ABTs radical 소거능은 Re 등의 방법(30)을 일부 수정하 여 실험하였다. ABTs $7 \mathrm{mM}$ 과 potassium persulfate 2.45 $\mathrm{mM}$ 을 증류수에 용해하여 12 16시간 동안 암소에 방치하 여 $\mathrm{ABTs}$ cation radical(ABTS $\left.{ }^{+}\right)$을 형성시켰다. 이 용액을
$80 \%$ ethanol을 이용하여 $734 \mathrm{~nm}$ 에서 $0.700 \pm 0.002$ 의 흡광도 값을 갖도록 희석하였다. 증류수에 희석한 시료 추출물 50 $\mu \mathrm{L}$ 를 시험관에 가한 다음 희석된 $\mathrm{ABTS}^{+}$용액 $3 \mathrm{~mL}$ 를 첨가하였다. 실온에서 6 분간 반응시켜 UV-visible spectrophotometer(UV-1601, Shimadzu Co.)를 이용하여 $734 \mathrm{~nm}$ 에서 흡광도를 측정하였다.

\section{Nitrite 소거활성 측정}

Nitrite 소거 활성은 시료 $1 \mathrm{~mL}$ 에 $1 \mathrm{mM} \mathrm{NaNO}$ 용액 1 $\mathrm{mL}$ 을 첨가하고, $0.1 \mathrm{~N} \mathrm{HCl}(\mathrm{pH}$ 1.2)로 전체 부피를 $10 \mathrm{~mL}$ 로 정용하였다. 이 용액을 $37^{\circ} \mathrm{C}$ 에서 1 시간 동안 반응시킨 후 각 반응액 $1 \mathrm{~mL}$ 에 $2 \%$ acetic acid solution $5 \mathrm{~mL}$ 과 Griess 시약(30\% acetic acid 로 조제한 $1 \%$ sulfanilic acid 와 $1 \%$ naphtylamine 의 $1: 1$ 혼합액) $0.4 \mathrm{~mL}$ 을 가하여 실온에서 15 분간 반응시킨 후 UV-visible spectrophotometer(UV1601, Shimadzu Co.)를 이용하여 $520 \mathrm{~nm}$ 에서 흡광도를 측 정하여 nitrite 소거활성을 측정하였다(31). 대조구는 증류 수를 사용하였다.

Salvianolic acid B, cryptotanshinone, tanshinone I, 및 tanshinone IIA분석

단삼의 유효 성분인 salvianolic acid B, cryptotanshinone, tanshinone I 및 tanshinone $\Pi \mathrm{A}$ 는 HPLC(1260 Infinity Quaternary LC System, Agilent Technologies, Waldbronn, Germany)를 이용하여 분석하였으며, 분석 조건은 Table 2 와 같다. 함량 측정은 표품 salvianolic acid B, cryptotanshinone, tanshinone I 및 tanshinone $\Pi \mathrm{A}$ 을 이용하여 작성한 검량선 의 희귀식에서 구하였다.

Table 2. HPLC conditions for the assay of Salvia miltiorrhiza Bunge

\begin{tabular}{|c|c|c|c|}
\hline Items & \multicolumn{3}{|c|}{ Conditions } \\
\hline HPLC system & \multicolumn{3}{|c|}{1260 (Infinity Quaternary LC System, Agilent Technologies, Waldbronn, Germany) } \\
\hline Column & \multicolumn{3}{|c|}{ ODS-H80 (ODS-H80, 4.6×250mm, YMC Co., Ltd., Kyoto, Japan) } \\
\hline \multirow[t]{7}{*}{ Mobile phase } & Time (min) & $1 \%$ formic acid in $\mathrm{H}_{2} \mathrm{O}$ & $1 \%$ formic acid in $\mathrm{ACN}: \mathrm{MeOH}(75: 25)$ \\
\hline & 0 & 75 & 25 \\
\hline & 1 & 60 & 40 \\
\hline & 14 & 60 & 40 \\
\hline & 22 & 40 & 60 \\
\hline & 23 & 11 & 89 \\
\hline & 45 & 11 & 89 \\
\hline Flow rate & \multicolumn{3}{|c|}{$0.5 \mathrm{~mL} / \mathrm{min}$} \\
\hline Column temp. & \multicolumn{3}{|c|}{$30^{\circ} \mathrm{C}$} \\
\hline Injection volume & \multicolumn{3}{|c|}{$5 \mu \mathrm{L}$} \\
\hline Detector & \multicolumn{3}{|c|}{ UV $(280 \mathrm{~nm})$} \\
\hline
\end{tabular}




\section{통계처리}

본 연구의 모든 실험은 3회 반복하여 측정한 평균과 표준 편차로 나타내었으며, 각 실험결과에 대한 통계분석은 PASW Statistics(18.0, SPSS Inc., Chicago, IL, USA)를 이용 하였다. 실험군 간의 유의적 차는 일원배치 분산분석법 (One-way Analysis of Variance)을 시행하였고, Duncan's multiple range test로 각 실험군의 평균치 간의 유의적 차이 를 검증하였다 $(\mathrm{p}<0.05)$.

\section{결과 및 고찰}

\section{단삼추출물의 추출수율, $\mathrm{pH}$ 및 당도 변화}

국내산 단삼을 이용한 추출물의 추출수율, $\mathrm{pH}$ 및 당도 변화를 조사한 결과는 Table 3 에 나타내었다. 효소제 종류 및 효소 처리 온도에 따라 차이를 나타내었다. 단삼추출물 의 추출수율은 $45^{\circ} \mathrm{C}$ 에서, 효소 무처리구 $35.4 \%$ 로 가장 낮았 으며, $60^{\circ} \mathrm{C}$, amylase계 효소를 처리한 구에서 $58.3 \%$ 로 가장 높게 나타났으며, 처리온도가 높을수록 추출수율이 많아지 는 경향을 나타내었다. Lee 등(32)의 효소제를 이용한 감태 추출물에 관한 연구에서는 비교적 추출수율이 높은 효소추 출물에서 우수한 항산화 활성이 나타났다고 보고된 바 있 다. 효소제 종류에 따른 단삼 추출물의 $\mathrm{pH}$ 변화를 조사한 결과는 $45^{\circ} \mathrm{C}$ 에서 효소 무처리구는 $\mathrm{pH} 5.87$ 이었으나, amylase계 효소를 사용하여 $60^{\circ} \mathrm{C}$ 에서 4 시간 처리구는 $\mathrm{pH}$ 6.04 로 가장 높게 나타내었다. 효소제 종류에 따른 당도의 변화는 효소 처리 유무 및 효소제 종류에 따른 변화를 나타 내었다. $45^{\circ} \mathrm{C}$, 효소 무처리구는 $2.67^{\circ} \mathrm{Brix}$ 로 가장 낮으며, 효소제를 사용한 추출물의 당도는 추출수율의 증가와 함께

Table 3. Changes in the extraction yield, $\mathrm{pH}$, and sugar content of Salvia miltiorrhiza Bunge extracts

\begin{tabular}{ccccc}
\hline $\begin{array}{c}\text { Extract Temp. } \\
\left({ }^{\circ} \mathrm{C}\right)\end{array}$ & Enzymes & $\begin{array}{c}\text { Extract yield } \\
(\%)\end{array}$ & $\mathrm{pH}$ & $\begin{array}{c}\text { Sugar content } \\
\left({ }^{\circ} \mathrm{Brix}\right)\end{array}$ \\
\hline & control & $35.4 \pm 0.5^{\mathrm{d} 1)}$ & $5.87 \pm 0.06^{\mathrm{cd}}$ & $2.67 \pm 0.06^{\mathrm{e}}$ \\
& $\mathrm{A}^{2)}$ & $48.2 \pm 0.4^{\mathrm{a}}$ & $5.88 \pm 0.00^{\mathrm{c}}$ & $5.70 \pm 0.00^{\mathrm{a}}$ \\
45 & $\mathrm{~B}$ & $37.3 \pm 0.6^{\mathrm{c}}$ & $5.89 \pm 0.01^{\mathrm{b}}$ & $5.17 \pm 0.06^{\mathrm{c}}$ \\
& $\mathrm{C}$ & $42.0 \pm 0.6^{\mathrm{b}}$ & $5.92 \pm 0.01^{\mathrm{a}}$ & $5.10 \pm 0.10^{\mathrm{d}}$ \\
& $\mathrm{D}$ & $42.3 \pm 0.6^{\mathrm{b}}$ & $5.87 \pm 0.01^{\mathrm{d}}$ & $5.40 \pm 0.00^{\mathrm{b}}$ \\
\hline & control & $52.3 \pm 0.6^{\mathrm{e}}$ & $5.99 \pm 0.01^{\mathrm{d}}$ & $2.70 \pm 0.00^{\mathrm{e}}$ \\
& $\mathrm{A}$ & $58.3 \pm 0.6^{\mathrm{a}}$ & $6.04 \pm 0.01^{\mathrm{a}}$ & $5.97 \pm 0.06^{\mathrm{a}}$ \\
& $\mathrm{B}$ & $53.3 \pm 0.5^{\mathrm{d}}$ & $5.94 \pm 0.01^{\mathrm{b}}$ & $5.50 \pm 0.10^{\mathrm{c}}$ \\
& $\mathrm{C}$ & $54.3 \pm 0.5^{\mathrm{c}}$ & $5.89 \pm 0.00^{\mathrm{c}}$ & $5.37 \pm 0.23^{\mathrm{d}}$ \\
& $\mathrm{D}$ & $56.3 \pm 0.5^{\mathrm{b}}$ & $5.93 \pm 0.00^{\mathrm{b}}$ & $5.73 \pm 0.06^{\mathrm{b}}$ \\
\hline
\end{tabular}

${ }^{11)}$ Values are mean $\pm S D(n=3)$. Means with different superscripts in the same row are significantly different $(\mathrm{p}<0.05)$ by Duncan's multiple range test.

${ }^{2)} \mathrm{A}$, Glucoamylase of amylase system; B, Cellulase of cellulase system; C, Rapidase C80 Max of pectinase system; D, ProteAX of protease system.
높은 온도에서 처리한 구간에서 증가하는 경향으로 나타났 으며, amylase계 효소를 사용하여 $60^{\circ} \mathrm{C}, 4$ 시간 처리구에서 $5.97^{\circ} \mathrm{Brix}$ 로 가장 높게 나타났다. Pectinase계 효소를 이용하 여 $45^{\circ} \mathrm{C}, 4$ 시간 처리구에서 $5.10^{\circ} \mathrm{Brix}$ 로 효소 처리를 한 구간 에서는 가장 낮은 당도를 나타내었다.

\section{단삼추출물의 색도 및 갈색도 변화}

효소제를 이용한 국내산 단삼 추출물의 색도 및 갈색도 변화를 조사한 결과는 Table 4에 나타냈으며, 효소제 종류 및 효소 처리 온도에 영향을 받는 것으로 나타났다. 색도는 $45^{\circ} \mathrm{C}$ 추출 효소 무처리구의 $\mathrm{L}, \mathrm{a}, \mathrm{b}$ 값은 $43.27,16.36$ 및 27.18로 적갈색을 나타냈으나, pectinase계 효소제를 이용 하여 $45^{\circ} \mathrm{C}$ 에서 4 시간 처리한 구는 $39.45,9.44$ 및 22.78 로 $\mathrm{L}$ 및 $\mathrm{b}$ 값이 가장 낮았으며 옅은 황적색을 보였다. Amylase 계 효소를 이용하여 $60^{\circ} \mathrm{C}$ 에서 4 시간 처리구는 $65.06,9.81$ 및 35.13의 밝은 황적색으로 $\mathrm{L}$ 값과 $\mathrm{b}$ 값이 가장 높게 나타났다.

효소 처리를 한 단삼 추출물의 갈색도 변화는 $45^{\circ} \mathrm{C}$ 에서 효소 무처리구가 1.81 로 가장 낮게 나타났으며, $60^{\circ} \mathrm{C}$ 추출 amylase계 효소 4시간 처리구에서 2.48로 가장 높았으며, cellulase계 효소를 이용하여 $45^{\circ} \mathrm{C}$ 에서 4 시간 처리구에서 2.36으로 비교적 높은 흡광도를 나타내었다. 식품 성분 중 질소화합물은 열처리 과정에서 갈변 반응을 일으켜 갈색 색소 및 행가 성분을 생성하며, 이 과정에서 생성된 amino-carbonyl 반응 생성물은 항산화 능력을 지니는 것으 로 알려져 있다(33).

Table 4. Changes in the Hunter's color value and browning degree of Salvia miltiorrhiza Bunge extracts

\begin{tabular}{|c|c|c|c|c|c|}
\hline \multirow{2}{*}{$\begin{array}{l}\text { Extract Temp. } \\
\left({ }^{\circ} \mathrm{C}\right)\end{array}$} & \multirow{2}{*}{ Enzymes } & \multicolumn{3}{|c|}{ Hunter's color value } & \multirow{2}{*}{$\begin{array}{c}\text { Browning } \\
\text { degree }\end{array}$} \\
\hline & & $\mathrm{L}$ & $\mathrm{a}$ & $\mathrm{b}$ & \\
\hline \multirow{5}{*}{45} & control & $43.27 \pm 0.03^{\mathrm{el})}$ & $9.80 \pm 0.01^{\mathrm{b}}$ & $28.44 \pm 0.03^{\mathrm{b}}$ & $1.81 \pm 0.01^{\mathrm{c}}$ \\
\hline & $A^{2)}$ & $57.98 \pm 0.01^{\mathrm{a}}$ & $9.14 \pm 0.01^{d}$ & $31.02 \pm 0.01^{\mathrm{a}}$ & $1.64 \pm 0.01^{\mathrm{d}}$ \\
\hline & B & $44.39 \pm 0.01^{\mathrm{d}}$ & $10.04 \pm 0.01^{\mathrm{a}}$ & $24.81 \pm 0.01^{\mathrm{d}}$ & $2.02 \pm 0.01^{\mathrm{b}}$ \\
\hline & $\mathrm{C}$ & $39.45 \pm 0.02^{\mathrm{e}}$ & $9.44 \pm 0.02^{\mathrm{c}}$ & $22.78 \pm 0.01^{\mathrm{e}}$ & $2.09 \pm 0.03^{\mathrm{a}}$ \\
\hline & D & $46.87 \pm 0.09^{c}$ & $8.45 \pm 0.03^{\mathrm{e}}$ & $25.62 \pm 0.06^{\mathrm{c}}$ & $1.84 \pm 0.03^{\mathrm{c}}$ \\
\hline \multirow{5}{*}{60} & control & $51.31 \pm 0.01^{\mathrm{b}}$ & $16.36 \pm 0.01^{\mathrm{a}}$ & $27.18 \pm 0.02^{\mathrm{e}}$ & $2.25 \pm 0.01^{\mathrm{c}}$ \\
\hline & A & $65.06 \pm 0.01^{\mathrm{a}}$ & $11.81 \pm 0.00^{\mathrm{e}}$ & $35.13 \pm 0.01^{\mathrm{a}}$ & $2.48 \pm 0.01^{\mathrm{a}}$ \\
\hline & B & $56.64 \pm 0.01^{\mathrm{c}}$ & $13.78 \pm 0.03^{\mathrm{c}}$ & $32.27 \pm 0.01^{\mathrm{c}}$ & $2.36 \pm 0.01^{b}$ \\
\hline & $\mathrm{C}$ & $50.56 \pm 0.03^{d}$ & $12.37 \pm 0.01^{\mathrm{d}}$ & $30.12 \pm 0.02^{\mathrm{d}}$ & $2.24 \pm 0.11^{\mathrm{c}}$ \\
\hline & $\mathrm{D}$ & $57.05 \pm 0.11^{b}$ & $14.88 \pm 0.05^{b}$ & $33.87 \pm 0.08^{b}$ & $2.01 \pm 0.01^{\mathrm{d}}$ \\
\hline
\end{tabular}

${ }^{1)}$ Values are mean $\pm S D(n=3)$. Means with different superscripts in the same row are significantly different $(\mathrm{p}<0.05)$ by Duncan's multiple range test.

${ }^{2} \mathrm{~A}$, Glucoamylase of amylase system; B, Cellulase of cellulase system; C, Rapidase C80 Max of pectinase system; D, ProteAX of protease system.

단삼 추출물의 총 페놀성 화합물 함량 변화

식물에 존재하는 많은 phytochemical 중 phenol성 화합물 
은 그 함량이 높을수록 항산화 활성은 증가하며, 항콜레스 테롤 작용, 정장작용, 항암 및 항산화 작용 등의 생리적 효과도 높아지는 것으로 알려져 있으며(34), 여러 가지 화학 물질은 생체 내에서 산화적 대사과정을 거치면서 비로소 활성화되어 변이원성이나 발암성을 나타내는 경우가 많다 (35). 보통 항산화능을 나타내는 전자공여능의 활성과 총 페놀함량이 비례하는 경향을 나타낸다(36). 국내산 단삼을 이용한 추출물의 총 페놀성 화합물 함량을 조사한 결과는 Fig. 1에 나타내었다. 효소 처리 유무 및 효소 활성 온도에 따라 차이를 나타내고 있으며, 탄수화물의 함량이 비교적 높은 단삼은 amylase계 효소를 이용하여 $60^{\circ} \mathrm{C}, 4$ 시간 처리 구에서 $28.09 \mathrm{mg} / \mathrm{g}$ 로 가장 높은 총 페놀성 화합물 함량을 나타내었다. Yang 등(37)은 고온고압 처리한 수삼의 경우 에는 처리온도가 높아지고, 처리시간이 길어질수록 총 페 놀성 화합물의 함량이 증가된다는 보고와는 비슷한 결과를 나타내었다.

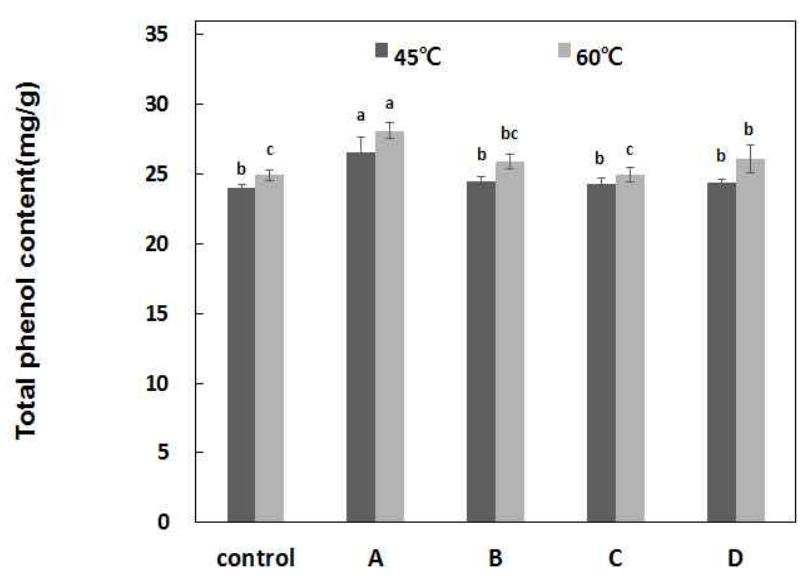

Fig. 1. Changes in the total phenolic content of Salvia miltiorrhiza Bunge extracts.

Values are mean $\pm \mathrm{SD}(\mathrm{n}=3)$. Means with different superscripts are significantly different $(\mathrm{p}<0.05)$ by Duncan's multiple range test. A, Glucoamylase of amylase system; B, Cellulase of cellulase system; C, Rapidase C80 Max of pectinase system; D, ProteAX of protease system.

\section{단삼추출물의 DPPH radical 소거능 변화}

국내산 단삼을 이용한 추출물의 DPPH radical 소거능을 조사한 결과는 Fig. 2에 나타냈으며, 효소제 종류에 따른 차이를 나타내며 효소 활성 온도가 높을수록 비교적 높은 활성 경향을 나타내었다. 단삼 추출물의 $55 \mathrm{ppm}$ 에서는 70\% 이상의 소거능을 나타내어 비교적 높은 항산화능을 보이 며, amylase계 효소를 $60^{\circ} \mathrm{C}$ 4시간 처리구의 $13.75 \mathrm{ppm}$ 에서 $35.99 \%, 27.50 \mathrm{ppm}$ 농도에서 $54.03 \%, 41.25 \mathrm{ppm}$ 에서 $68.94 \%$ 및 $55.00 \mathrm{ppm}$ 에서는 $84.25 \%$ 로 농도 의존적으로 $\mathrm{DPPH}$ radical 소거능이 높아지는 경향을 보였으며, $60^{\circ} \mathrm{C}$ 4시간 처리구의 $27.50 \mathrm{ppm}$ 농도에서 $50.0 \%$ 이상의 소거능 을 나타내었다. 페놀성 화합물 함량에 대한 많은 연구들이 $\mathrm{DPPH}$ radical에 대한 긍정적 상호관계를 보고(38)한 바와
비슷한 경향을 나타내고 있다. DPPH의 환원력은 항산화 활성과 연관성이 높아 다양한 천연소재로부터 항산화 물질 을 검색하는데 이용되고 있다(39). 효소 처리를 하지 않고 고온에서 열수 추출한 단삼 추출물의 DPPH 소거능을 연구 한 $\mathrm{YeO}(15)$ 의 결과에서 단삼 추출물의 25 및 $125 \mathrm{ppm}$ 농도 에서 37.84 및 $50.23 \%$ 를 나타냈다는 결과보다 효소를 이용 한 저온 추출법을 이용한 본 실험에서 높은 활성을 나타낸 것은 성분함량이 우수한 국내산 단삼을 이용하여 저온에서 효소 처리를 한 것이 유효성분의 안정성에 더 효과적인 것으로 판단된다.

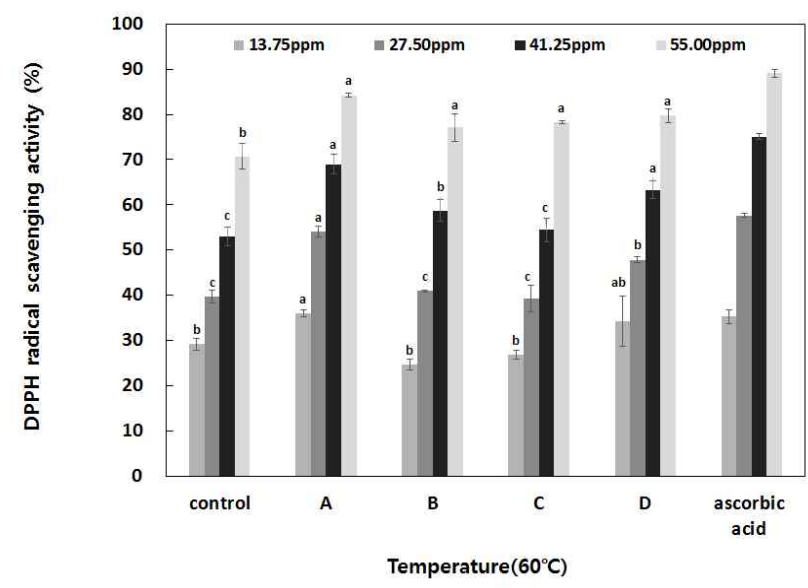

Fig. 2. Change in the DPPH radical scavenging activity of Salvia miltiorrhiza Bunge extracts.

Values are mean $\pm \mathrm{SD}(\mathrm{n}=3)$. Means with different superscripts are significantly different $(\mathrm{p}<0.05)$ by Duncan's multiple range test. A, Glucoamylase of amylase system; B, Cellulase of cellulase system; C, Rapidase C80 Max of pectinase system; D, ProteAX of protease system.

\section{단삼추출물의 $\mathrm{ABT}$ S radical 소거능 변화}

ABTs radical 소거활성은 수소공여항산화제(hydrogendonating antioxidants)와 연쇄 절단형 항산화제(chain-breaking antioxidants) 모두를 측정할 수 있으며, 수용상(aqueous phase)과 유기상(organic phase) 모두에 적용 가능한 측정 방법이다(30). 국내산 단삼을 이용한 추출물의 ABTs radical 소거능을 조사한 결과는 Fig. 3에 나타내었다. 효소 활성 온도가 높을수록 비교적 높은 활성을 나타내었으며, $60^{\circ} \mathrm{C}$ 에서 4시간 amylase계 효소 처리구의 $13.75,27.50,41.25$ 및 $55 \mathrm{ppm}$ 에서 $23.26,41.06,63.00$ 및 $84.11 \%$ 로 농도 의존적 으로 가장 높은 활성을 나타내었다. $\mathrm{Kim}$ 등(38)은 천연 한약 재를 이용하여 열수 및 메탄올 추출물의 총 페놀성 화합물 함량 변화를 연구한 결과 페놀성 화합물은 항산화 작용을 가진 대표적인 물질이며, 항산화성의 정도는 식물의 종류 및 이들에 함유되어 있는 항산화 유효성분의 종류와 추출방 법에 따라 현저히 차이가 있음을 보고한 바 있다.

\section{단삼 추출물의 아질산염 변화}

$\mathrm{NO}$ 는 분비조직과 세포의 기능에 영향을 미치며 세포성 


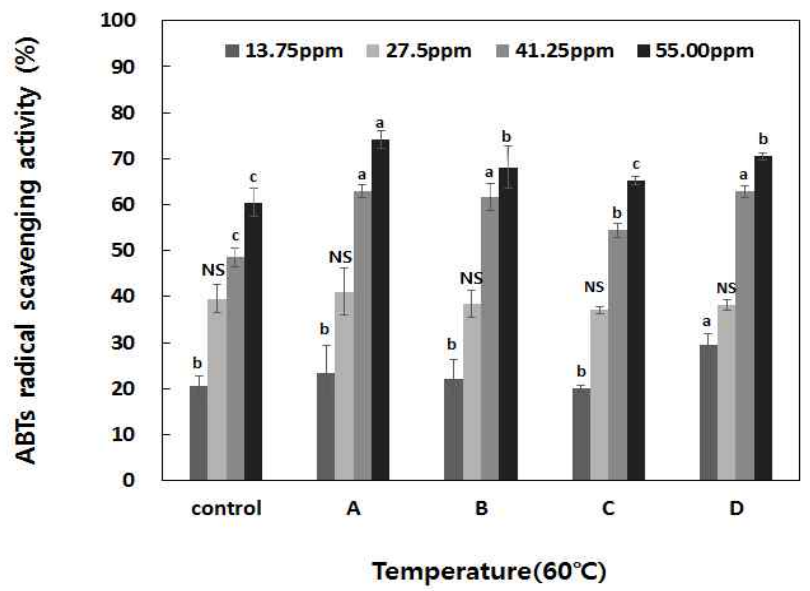

Fig. 3. Changes in the ABTS radical scavenging activity of Salvia miltiorrhiza Bunge extracts.

Values are mean $\pm \mathrm{SD}(\mathrm{n}=3)$. Means with different superscripts are significantly different $(\mathrm{p}<0.05)$ by Duncan's multiple range test. NS, not significantly different. A, Glucoamylase of amylase system; B, Cellulase of cellulase system; C, Rapidase C80 Max of pectinase system; D, ProteAX of protease system.

면역계의 주된 역할의 하나로 세포독성이나 성장억제작용 을 하며, NO 자신은 매우 약한 산화성을 가진 라디칼로서 vitamin E 와 비슷하게 세포의 지질과산화물을 막는 항산화 기능을 수행한다(36). 국내산 단삼 추출물 $55 \mu \mathrm{g} / \mathrm{g}$ 농도를 이용하여 $\mathrm{pH} 1.2$ 에서 반응시켜 아질산염 소거능을 조사한 결과는 Fig. 4에 나타내었으며 추출온도에 따른 차이를 보 이고 있다. Amylase계 효소를 이용하여 $60^{\circ} \mathrm{C}, 4$ 시간 처리구 에서 $71.78 \%$ 의 높은 활성을 나타냈으며, 그 다음이 protease 계 효소를 이용하여 $60^{\circ} \mathrm{C}, 4$ 시간 처리구에서 $67.37 \%$ 의 활성 을 나타냈다. $45^{\circ} \mathrm{C}$ 4시간 처리구에서 amylase계 효소를 사 용한 구에서 $62.09 \%$ 의 활성으로 다른 효소제를 이용한 구 간보다 높은 NO radical 소거 활성을 나타내었다.

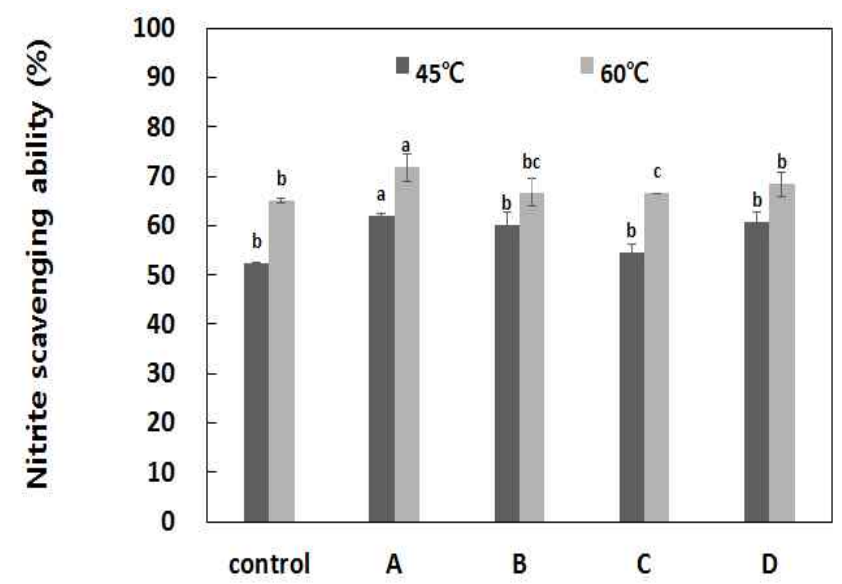

Fig. 4. Changes in the nitrite scavenging ability of Salvia miltiorrhiza Bunge extracts.

Values are mean $\pm \mathrm{SD}(\mathrm{n}=3)$. Means with different superscripts are significantly different $(\mathrm{p}<0.05)$ by Duncan's multiple range test. A, Glucoamylase of amylase system; B, Cellulase of cellulase system; C, Rapidase C80 Max of pectinase system; D, ProteAX of protease system.
Salvianolic acid B, cryptotanshinone 및 tanshinone I 함 량변화

Salvianolic acid B는 radical과 반응성이 높은 페놀성 수산 기를 7종이나 지니고 있으며, 가수분해, decarboxylation 등 의 반응에 더하여 radical과 반응까지 수반됨으로써 분해 반응은 가열에 의해 급속히 진행 될 것이라고 한 보고(39)가 있다. 단삼의 여러 성분 중 tanshinone I 은 활성화된 간성상 세포의 자가사멸을 유도하여 항섬유화 효과를 나타내는 효능이 발표(39)되었다.

국내산 단삼을 이용한 추출물의 유효성분 HPLC chromatogram 패턴은 Fig. 5와 같으며, 저온 효소처리 단삼 추출물의 유효성분 함량의 변화를 조사한 결과는 Table 5에 나타내었다. 효소 처리에 따른 유효성분의 변화는 추출 온 도 및 효소제 종류에 따라 변화를 나타내고 있으며 4종의 유효성분 중 salvianolic acid $\mathrm{B}$ 와 cryptotanshinone 및 tanshinone I 는 검출되었으나 tanshinone $\Pi \mathrm{A}$ 는 미량이 검 출되었다. Salvianolic acid B함량이 $45^{\circ} \mathrm{C}$ 효소 무처리구 $1,650.7 \mathrm{mg} \%$ 로 가장 낮게 나타났으며 $45^{\circ} \mathrm{C}, 4$ 시간 처리시 amylase계 효소 처리구에서 $2,583.8 \mathrm{mg} \%$ 로 가장 높은 함량 을 나타내었다. $60^{\circ} \mathrm{C}$ 에서 4 시간 처리구에서는 salvianolic acid B함량은 amylase계 효소 처리구에서 $2,397.6 \mathrm{mg} \%$ 으로 가장 높은 함량을 나타내었으며, pectinase계 효소 처리구에 서 낮은 함량을 나타내었다. Cryptotanshinone 함량은 $45^{\circ} \mathrm{C}$ 에서 4시간 효소 무처리구에서 $2.3 \mathrm{mg} \%$ 로 가장 낮게 나타 났으며, $60^{\circ} \mathrm{C}, 4$ 시간 amylase계 및 protease계 효소 처리구에 서 $3.8 \mathrm{mg} \%$ 으로 가장 높게 나타났다. Tanshinon I 함량은 $60^{\circ} \mathrm{C}, 4$ 시간 protease계 효소 처리구에서 $14.2 \mathrm{mg} \%$ 으로 가 장 높게 나타났다. 단삼성분의 정량에 대한 보고에서 중국 약전에 $75 \%$ 메탄올로 30 분 초음파 추출로 단삼의 salvianolic acid B 함량은 $3 \%$ 이상, tanshinone $\Pi \mathrm{A}$ 는 $0.2 \%$ 이상을 함유하도록 규정되어 있으며(22), 대한약전에서는

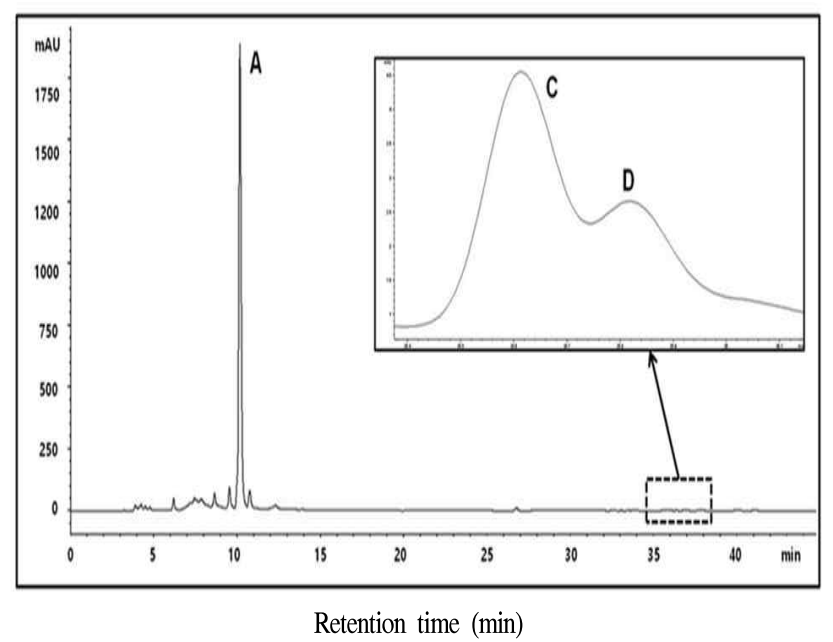

Fig. 5. HPLC chromatogram of Salvia miltiorrhiza Bunge extracts. A, Salvianolic acid B; C, Cryptotanshinone; D, Tanshinone I. 
$75 \%$ 메탄올로 30 분 초음파 추출시 salvianolic acid B 함량 $4.1 \%$ 이상으로 명시되어 있다(3). 본 실험에 사용한 단삼은 대한약전의 규격에 적합한 단삼을 활용하였으며, 본 저온 효소추출시 $75 \%$ 메탄올 용매로 추출시 단삼의 지표성분 함량대비 salvianolic acid B의 추출수율은 $56 ~ 77 \%$, tanshinone $\Pi \mathrm{A}$ 의 추출수율은 58 71\%의 범위로 나타났다. 효소중에서는 amylase계 효소를 이용시 지표성분의 추출수 율이 높고, 안정적 추출이 가능한 것으로 확인하였다.

Table 5. Levels of salvianolic acid B, cryptotanshinone, tanshinone I, and tanshinone IIA of Salvia miltiorrhiza Bunge extracts

\begin{tabular}{cccccc}
\hline $\begin{array}{c}\text { Extract } \\
\begin{array}{c}\text { Temp. } \\
\left({ }^{\circ} \mathrm{C}\right)\end{array}\end{array}$ & Enzymes & $\begin{array}{c}\text { Salvianolic } \\
\text { acid B }\end{array}$ & Cryptotanshinone & Tanshinone I & $\begin{array}{c}\text { Tanshinone } \\
\text { IIA }\end{array}$ \\
\hline & control & $1,650.7 \pm 13.2^{1)}$ & $2.3 \pm 0.1$ & $11.1 \pm 0.1$ & TR $^{2)}$ \\
& $\mathrm{A}^{3)}$ & $2,583.8 \pm 4.5$ & $2.8 \pm 0.1$ & $9.2 \pm 0.1$ & TR \\
45 & B & $2,493.3 \pm 9.7$ & $2.6 \pm 0.1$ & $9.1 \pm 0.1$ & TR \\
& C & $1,688.1 \pm 14.0$ & $2.6 \pm 0.1$ & $12.9 \pm 0.1$ & TR \\
& D & $2,379.1 \pm 16.5$ & $2.8 \pm 0.2$ & $13.6 \pm 0.1$ & TR \\
\hline & control & $2,397.6 \pm 3.5$ & $3.3 \pm 0.2$ & $11.7 \pm 0.1$ & TR \\
60 & A & $3,002.6 \pm 14.6$ & $3.8 \pm 0.1$ & $13.4 \pm 0.1$ & TR \\
& B & $2,933.6 \pm 15.0$ & $3.4 \pm 0.2$ & $13.2 \pm 0.1$ & TR \\
& C & $2,367.5 \pm 25.7$ & $3.4 \pm 0.1$ & $12.4 \pm 0.1$ & TR \\
& D & $2,975.6 \pm 4.0$ & $3.8 \pm 0.2$ & $14.2 \pm 0.2$ & TR \\
\hline
\end{tabular}

${ }^{1)}$ Values are means $\pm \mathrm{SD}(\mathrm{n}=3)$.

${ }^{2)}$ TR, Trace.

${ }^{3)} \mathrm{A}$, Glucoamylase of amylase system; B, Cellulase of cellulase system; C, Rapidase C80 Max of pectinase system; D, ProteAX of protease system.

\section{요 약}

본 연구는 국내산 단삼을 활용하여 amylase계, cellulase 계, pectinase계 및 protease계 효소제를 이용한 저온 추출법 에 따른 단삼 추출물의 이화학적 품질 변화를 조사하였다. 단삼 추출물의 수율, $\mathrm{pH}$, 당도 및 색도 변화는 amylase계 효소를 이용하여 $60^{\circ} \mathrm{C}, 4$ 시간 처리구에서 $58.3 \%, \mathrm{pH} 6.04$, $5.97^{\circ} \mathrm{Brix}$ 와 65.06(L) 및 35.13(b)로 가장 높게 나타났으며, $\mathrm{a}$ 값은 protease계 효소를 이용하여 $60^{\circ} \mathrm{C}$ 에서 처리구에서 14.88 로 붉은색을 나타내었다. 효소제를 이용한 단삼 추출 물의 항산화능은 추출농도 $55 \mathrm{ppm}$ 에서 $\mathrm{DPPH}$ 및 $\mathrm{ABTs}$ 소거능 84.25 및 $74.11 \%$ 로 amylase계 효소를 이용하여 6 $0^{\circ} \mathrm{C}, 4$ 시간 처리구에서 가장 높은 소거능을 나타내었다. 총 페놀성 화합물 함량은 $60^{\circ} \mathrm{C}$ 효소 처리구간들에서 비교적 높은 함량을 나타내었다. 단삼 추출물의 salvianolic acid $\mathrm{B}$ 함량은 $60^{\circ} \mathrm{C}$ 에서 4 시간, amylase계 효소구에서 3,002 $\mathrm{mg} \%$ 로 가장 높은 함량을 나타내었으며, cryptotanshinone
함량은 $60^{\circ} \mathrm{C} 4$ 시간 amylase 및 protease계 효소 처리구에서 $3.8 \mathrm{mg} \%$ 으로 가장 높게 나타났으며, tanshinon I 함량은 $60^{\circ} \mathrm{C}$ 4시간 protease계 효소구에서 $14.2 \mathrm{mg} \%$ 으로 가장 높게 나타났다. 이상의 결과로 amylase계 효소를 이용하여 단삼 의 저온 효소 추출시 단삼 추출물의 지표성분의 안정적 추출이 가능한 바, 기능성 소재로서 대량생산을 통한 산업 적 이용이 가능할 것으로 판단되며, 효소제를 이용한 저온 효소추출법은 천연물의 다양한 원료에 접목시킬 수 있을 것으로 생각된다.

\section{감사의 글}

본 연구는 농림축산식품부와 농림기술평가원의 지원으 로 수행되는 2014년의 『국내산 단삼의 고랭지 재배기술 및 유효성분 강화 가공기반 구축(114112-1)』과제일환으로 이루어졌으며, 이에 감사드립니다.

\section{References}

1. Kim KS, Kim SG, Chae SK, Kim BS (2013) Analysis on patent trends in nonthermal processing technologies for medicinal herbs. Korean J Oriental Physiol Pathol, 27, 367-373

2. King MB, Bott TR (1993) Extraction of natural products using near-critical solvent. Chapman \& Hall, London, p 21

3. Park SH, Hwang HS, Han JH (2004) Development of drink from composition with medicinal plants and evaluation of its physiological function. Korean Nutr Soc, 37, 364-372

4. Sung NS, Jung HY, Choi JH, Lee SC, Choi BH, Park SS (2014) Preparation of functional healthy drinks by Acanthopanax senticosus extracts. J Life Sci, 24, 959-966

5. Lee SJ, Kim EH, Lee HG (2008) Development of rice wines using Cornus Offinalis and Scutellaria Baicalensis by antioxidant activity tests. Korean J Food Sci Technol, $40,21-30$

6. Lee JM, Lee HN, Chang YH (2013) Quality characteristics of Makgeolli using Angelica gigas Nakai water extracts. J East Asian Soc Dietary Life, 23, 332-340

7. Lee JS (2009) Physicochemical properties of Angelica gigas $\mathrm{N}$. and qualitative characteristics of Korea rice cake added with Angelica gigas N. Ph D Thesis, Sejong University, Seoul, Korea

8. Park GS, An SH (2012) Quality characteristics of pound 
cake added with Angelica gigas Nakai powder. Korean J Food Cookery Sci, 28, 463-471

9. Kang CS, Lee MJ, Park CB, Bang IS (2012) Study on the antioxidative and physiological activities of Saururus chinensis extract. J Life Sci, 22, 807-814

10. Yang MO (2013) Antioxidant and sensory properties of hot water extract of Liriope Tubers treated at various preprocess. J East Asian Soc Dietary Life, 23, 645-653

11. Ryu HY, Kim YK, Kwun IS, Kwon CS, Jin IN, Sohn HY (2007) Thrombin inhibition activity of fructus extract of Crataegus pinnatifida Bunge. J Life Sci, 17, 535-539

12. Kim DH, Park JH, Kim JH, Kim CH, You JH, Kwon MC, Lee HY (2005) Enhancement of immune activities of Ephedrae Herba and Rubi Fructus at low temperature extraction. Korean J Medicinal Crop Sci, 13, 81-86

13. Lee HJ, Jeong HS, Park CG, Lee JH, Park CB, Kim CT, Choi AJ (2014) A study on isolation of polysaccharides from Angelica gigas Nakai by enzyme treatments. Food Eng Prog, 18, 406-412

14. Kwon SC, Choi GH, Hwang JH, Lee KH (2010) Physicochemical property and antioxidative activity of hot-water extracts from enzyme hydrolysate of Astragalus membranaceus. J Korean Soc Food Sci Nutr, 39, 406-413

15. Yeo IH (2012) Effects of Salviae Miltiorrhizae Radix hat aqueous extract on No, PGE2, production and DPPH radical scavenging in macrophage. MS Thesis. Semyung University, Chungbuk, Korea

16. Han WS, Jeong SI (2000) Studies on the constituents of Salvia militorrhiza Bunge. J Mokwon Institute Natural Science, 9, 11-14

17. Kim JK (1989) Ilustrated natural drugs encyckopedia, Namsandong Publishers, Seoul, Korea, p 160

18. Food Code (2011), Ministry of Food and Drug Safety, p 1122

19. Fugh-Berman A (2000) Herbs and dietary supplements in the prevention and treatment of cardiovascular disease. Prev Cardiol, 3, 24-32

20. Mok JS, Park UY, Kim YM, Chang DS (1994) Effects of solvents and extracting condition on the antimicrobial activity of Salviae miltiorrhizae radix (Salvia miltiorrhiza) extract. J Korean Soc Food Nutr, 23, 1001-1007

21. Shon YH, Cho HJ, Chang HW, Son KH, Nam KS (2006) Chemopreventive potential of Salviae Miltiorrhizae fraction extracts. J Life Sci, 16, 369-374

22. Jeon SJ (2007) Studies on the chemical analysis and anti-inflammatory acitivities of the components isolated from the Salvia miltiorrhiza Bunge. Ph D Thesis, Andong
National University, Gyeongbuk, Korea

23. Yun HJ, Heo SK, Park WH (2007) Anti-inflammatory effect of Salviae Miltiorrhizae Radix. Korean J Herbol, 22, 65-73

24. Kim CW (2009) Crytotanshinone, a lipophilic compound of Salvia miltiorriza root, inhibits TNF-a-induced expression of adhesion molecules in HUVEC and attenuates rat myocardial ischemia/reperfusion injury in vivo. MS Thesis. Gyeongsang National University, Gyeongnam, Korea

25. Yang, WH (2012) Cytotoxic effect of the Salvia miltiorrhiza Bunge extracts on the cancer cell lines. MS Thesis. Dongshin University, Jeonnam, Korea

26. Lee HJ, Cho JY, Lee SH, Jeon TI, Park KH, Moon JH (2012) Chemical conversion pattern of Salvianolic acid $B$ in aqueous solution under different decoction conditions. Korean J Food Sci Technol, 44, 692-698

27. Lee SE, Cho SI (2015) Anti-inflammatory effects of Salviae Miltiorrhizae Radix extract on RAW 264.7 cell via anti-oxidative activites. Korean J Herbol, 30, 89-94

28. Kwon JH, Belanger JMR, Pare JRJ (2003) Optimization of microwave assisted extraction (MAP) for ginseng components by response surface methodology. J Agric Food Chem, 51, 1807-1810

29. Blosis MS (1958) Antioxidant determination by the use of a stable free radical. Nature, 181, 1199-1200

30. Re R, Pellegrini N, Proteggente A, Pannala A, Yang M, Rice-Evans C (1999) Antioxidant activity applying an improved ABTs radical cation decolorization assay. Free Radic Biol Ned, 26, 1231-1237

31. Boo HO, Lee HH, Lee JW, Hwang SJ, Park SU (2009) Different of total phenolics and flavonoids, radical scavenging activities and nitrite scavenging effects of Momordica charantia L. according to cultivars. Korean J Med Crop Sci, 17, 15-20

32. Lee SH, Kim KN, Cha SH, Ahn GN, Jeon YJ (2006) Comparison of antioxidant activities of enzymatic and methanolic extracts from Ecklonia cava stem and leave. J Korean Soc Food Sci Nutr, 35, 1139-1145

33. Lee JW, Park CK, Do JH (2005) Antioxidative activity of the water soluble browning reaction products isolated from Korean Red Ginseng. J Ginseng Res, 29, 44-48

34. Chaudicre J, Ferrari-Iliou R (1999) Intracellular antioxidants : from chemical to biochemical mechanisms. Food Chem Toxicol 37, 949-962

35. Kim SK, Ban SY, Kim JS, Chung SK (2005) Change of antioxidant activity and antioxidant compounds in 
Saururus chinensis by extraction conditions. J Korean Soc Appl Biol Chem, 48, 89-92

36. Kim HK (2009) Anti-inflammatory effect of Liriopis tuber water extract. Ph D Thesis. Kyungwon University, Gyeongbuk, Korea

37. Yang SJ, Woo KS, Yoo JS, Kang TS, Noh YH, Lee JS, Jeong HS (2006) Changes of Korean ginseng components with high temperature and pressure treatment. Korean J Food Sci Technol, 38, 521-525
38. Kim JH, Kang Ym, Eum GS, Ko YM, Kim TY (2003) Antioxidative activity and antimicrobial activity of extracts from medicinal plants (Akebia quinate Decaisn, Scirusfluviatilis A Gray, Gradenia jasminoides for. grandiflora Makino). J Agric Life Sci, 37, 69-75

39. Lee HJ, Cho JY, Moon JH (2012) Chemical conversions of Salvianolic acid B by decoction in aqueous solution. Fitoterapia, 83, 1196-1204 